Toxicology, 28 (1983) 17-28

Elsevier Scientific Publishers Ireland Ltd.

\title{
RODENT CARCINOGENESIS BIOASSAY WITH OXISURAN, A SELECTIVE IMMUNOSUPPRESSIVE AGENT
}

\author{
FELIX A. DE LA IGLESIA and EDWARD J. McGUIRE \\ Department of Pathology and Experimental Toxicology, Warner-Lambert/Parke-Davis \\ Pharmaceutical Research Division, Warner-Lambert Company, Ann Arbor, MI 48105 and \\ Department of Environmental and Industrial Health Sciences, School of Public Health, \\ University of Michigan, Ann Arbor, MI 48109 (U.S.A.)
}

(Received October 7th, 1982)

(Accepted January 7th, 1983)

\begin{abstract}
The carcinogenic potential of oxisuran, a synthetic immunosuppressive agent, was studied for 80 weeks and 104 weeks in mice and rats, respectively. Groups of 50 mice and 70 rats of each sex received oxisuran at doses of 600 , 240 , and $40 \mathrm{mg} / \mathrm{kg} /$ day as dietary admixtures over the entire experimental period. Adequate survival rates allowed accurate statistical analysis of diagnosed neoplasia. Increased susceptibility to tumor development was not clearly demonstrated. In mice the only statistically significant increase in the incidence of malignancy was lung carcinomas in high dose females $(P<0.05)$. However, lung carcinoma incidence was significantly decreased in mid- and low-dose male mice when compared to spontaneous control rates $(P<0.01)$. Although not confirmed statistically, there was an increased incidence of lung carcinomas and liver cell adenomas in high dose male mice, and increased lymphoid tumors in all female treated groups. In rats, the incidence of liver cell adenomas in high dose animals of both sexes was increased, although confirmed statistically in males only $(P<0.01)$. In high dose females, significantly decreased incidences of mammary fibroadenomas, pituitary chromophobe adenomas, and thyroid parafollicular cell tumors $(P<0.01)$ contributed to an overall decrease in both benign tumors and in the combined benign and malignant tumor rates.
\end{abstract}

Key words: Carcinogenesis; Immunosuppressant; Tumor immunology

Address all correspondence to: Felix A. de la Iglesia, Department of Pathology and Experimental Toxicology, Warner-Lambert/Parke-Davis Pharmaceutical Research Division, Warner-Lambert Company, Ann Arbor, MI 48105, U.S.A.

$0300-483 \times / 83 / \$ 03.00$

(c) 1983 Elsevier Scientific Publishers Ireland Ltd.

Printed and Published in Ireland 


\section{INTRODUCTION}

Current concepts linking immunologic mechanisms to cancer would indicate that depressed immune responses increase susceptibility to the development of neoplasms. Thus, inhibition of tissue-mediated immune response in "nude" mice would result in increased tumor formation when maintained for almost 2 years under germ-free conditions [1]. Thomas and Burnet conceptualized the theory of immunologic surveillance and reasoned that malignancies elicit a protective immunologic reaction, possibly similar to the type that destroys grafts of foreign tissues [2,3]. Oxisuran has been characterized as a differential inhibitor of cell-mediated hypersensitivity that suppresses allograft immunity, without concomitant suppression of humoral antibody formation that may deprive the host of normal immunological defenses $[4,5]$. This compound prolonged the survival of skin allographs in mice and rats, but did not suppress the response of normal or grafted mice to an immunogen, sheep erythrocytes. Long-term carcinogenicity bioassays of oxisuran in rats and mice were undertaken to determine whether the compound would elicit tumorigenic potential. Increased susceptibility to cancer formation was not demonstrated unequivocally, and although other mechanisms cannot be excluded, the reduced incidence of certain tumor types in rats may be mediated through immunosuppression.

Various mechanisms of tumor formation, and the immunogenic nature of various tumors in a variety of species may account for the increased tendency towards tumor formation in some instances and decreased in others [6].

\section{MATERIALS AND METHODS}

\section{Chemical}

Oxisuran, 2[(methylsulfinyl)acetyl]-pyridine (Fig. 1), is a non-hygroscopic off-white crystalline material with a molecular weight of 183.2 and a melting point of $71-72^{\circ} \mathrm{C}$; it is readily soluble in water, propylene glycol, and ethanol.

\section{Animals and housing}

Random bred, barrier raised albino $\mathrm{CF}_{1}$ mice and albino Wistar rats were supplied by Carworth Farms, New City, NY and Hilltop Caviary, Scottdale, $\mathrm{PA}$, respectively. The animals were approximately 42 days of age at the initiation of study. These animal strains were selected based upon the wealth of historical data accumulated in this laboratory since the inception of the<smiles>CS(=O)CC(O)c1ccccn1</smiles>

Fig. 1. Oxisuran: 2-[(methylsulfinyl)acetyl]-pyridine. 
carcinogenesis bioassay program in 1967 . The strains have been genetically stable with adequate survival rates at 80 weeks for mice and 104 weeks for rats, moderate incidence of spontaneous neoplasia, and low incidence of intercurrent pathology.

Animals in substandard clinical condition were culled during a 2-week quarantine period. Rats selected for study were housed individually in suspended stainless steel cages while groups of 3 mice were housed in plastic boxes with pressed hardwood bedding chips. Some male mice were separated into individual units as a result of aggressive behavior. The animals were maintained in clean rooms with controlled temperature $\left(23 \pm 2^{\circ} \mathrm{C}\right)$ and relative humidity $(40-60 \%)$, together with 18 fresh air exchanges and an 11-h photoperiod. The species were housed in separate animal rooms. Fresh water was supplied ad libitum. Animals were weighed once weekly for the initial 6 months of study and once every 2 weeks thereafter. Food consumption was measured weekly throughout the entire experimental period. From these data, drug levels in diet were adjusted weekly to compensate for changes in mean body weight and food consumption. Rats received $180 \mathrm{~g}$ of drug-diet admixture weekly while mice were given $60 \mathrm{~g}$ quantities.

All animals were observed at least once daily for evidence of overt toxicity. Complete physical examinations were performed pretest and monthly thereafter. Ophthalmic examinations were performed on all mice at pretest and at 28,52 , and 80 weeks and in rats at pretest, and at $6,12,18$, and 24 months. Ten rats per sex group were sacrificed at 26 and 78 weeks. Clinical laboratory studies were conducted on rats sacrificed at 6,18 , and 24 months. These clinical and laboratory data, other than those needed for carcinogenesis assessment, have not been included in this paper for the sake of brevity.

\section{Experimental groups}

Dose levels selected for these experiments were based upon an overall assessment of effects encountered in previous acute, subacute, and longterm toxicology studies [7]. Groups of 50 mice and 70 rats of each sex received oxisuran at 600,240 , and $40 \mathrm{mg} / \mathrm{kg} /$ day. The untreated control group consisted of 100 mice and 120 rats of each sex.

\section{Pathology studies}

Animals found dead or extremely debilitated were sacrificed for humane reasons and to minimize onset of autolytic changes in the event of death. All animals were autopsied; those sacrificed in extremis were considered deaths for the purposes of data analysis. In animals sacrificed terminally, absolute organ weights and organ to body weight ratios were determined for gonads, liver, kidneys, prostate and uterus. In rats, thyroid and adrenal weights also were recorded. Following gross examinations, tissues and gross abnormalities from all animals were processed and evaluated microscopically. A blood smear was obtained from mice with suspected lymphoid tumors in order to attempt the classification of these neoplasia. 


\section{Method of tumor analysis}

All tumors noted upon gross examination were subjected to microscopic confirmation. The technique for statistical analysis has been described previously [8]. Briefly, the time of onset of all tumors was set when they were first noted in the in vivo phase. The onset of internal, nonpalpable tumors was established at the time of autopsy. The criteria for tumorigenic response was based on histotyping of tumors, positive dose relationships, statistically significant differences in tumor rates, changes in onset, average onset, or latency, and the occurrence of highly unusual or unexpected tumors.

\section{RESULTS}

Survival data for animals fed the various drug regimens are presented in Figs. 2 and 3 for mice and rats, respectively. Group survival rates in both mice $(40-66 \%)$ and rats $(29-52 \%)$ ensured adequate statistical power for tumor analysis. Reduced rat survival rates were influenced by the 26 week and 78 week interim sacrifice of 10 animals/sex group at each interval. The animals maintained satisfactory clinical condition throughout the studies. Clinical signs were primarily related to aggressive behavior of male mice and aging changes in both species. In female rats, the incidence of grossly palpable
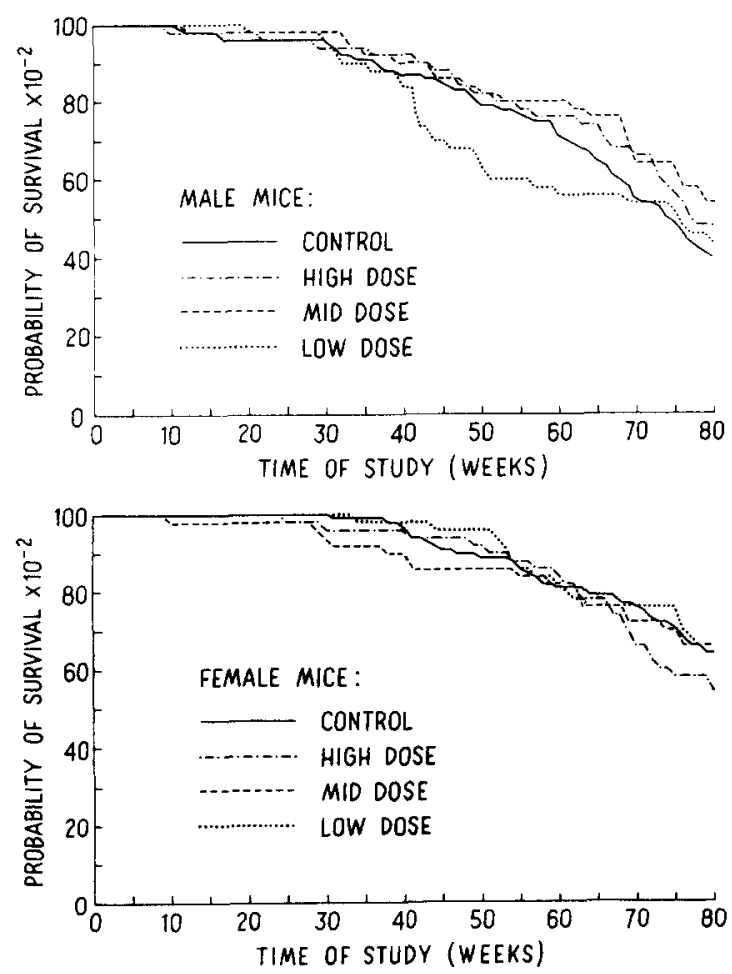

Fig. 2. Probability of survival of mice fed oxisuran for 80 weeks. 

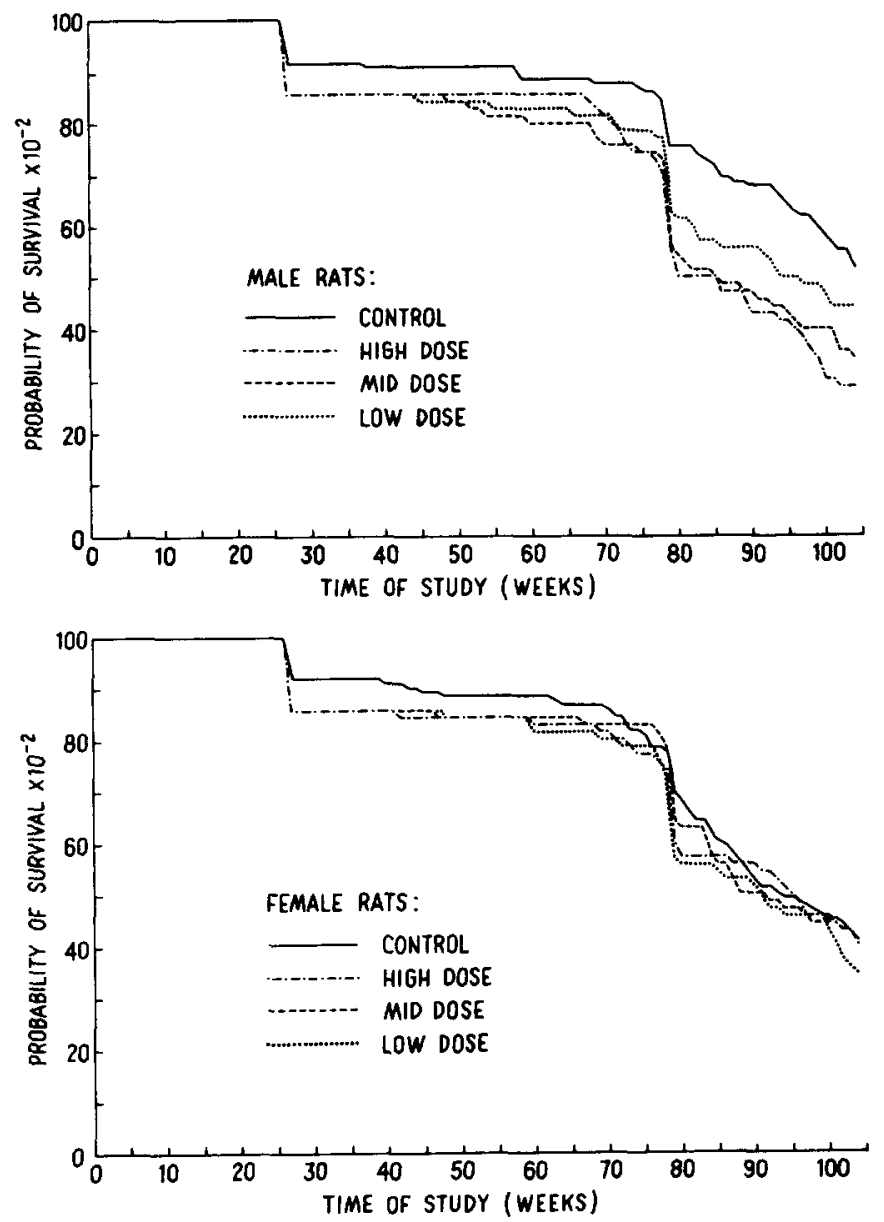

Fig. 3. Probability of survival of rats fed oxisuran for 104 weeks.

mammary nodules in mid, low, and control groups appeared similar $(29,23$, and $28 \%$, respectively), but was apparently decreased in high dose females (13\%). In female mice, mammary nodules were palpated in $10,8,10$, and $9 \%$ of high, mid, and low dose animals and untreated controls, respectively.

Body weight gain suppression at termination was apparent only in rats in the high and mid dose groups.

No body, liver or kidney weight differences were noted in the various groups of mice (Table I). In male and female rats, absolute liver weight and liver/100 $\mathrm{g}$ body weight ratios were increased, as were the absolute and relative kidney weights at 104 weeks.

Histopathologically, the only non-neoplastic change associated with treatment in rats was a dose-related ground glass appearance of hepatocyte cytoplasm, which represented proliferating smooth endoplasmic reticulum 


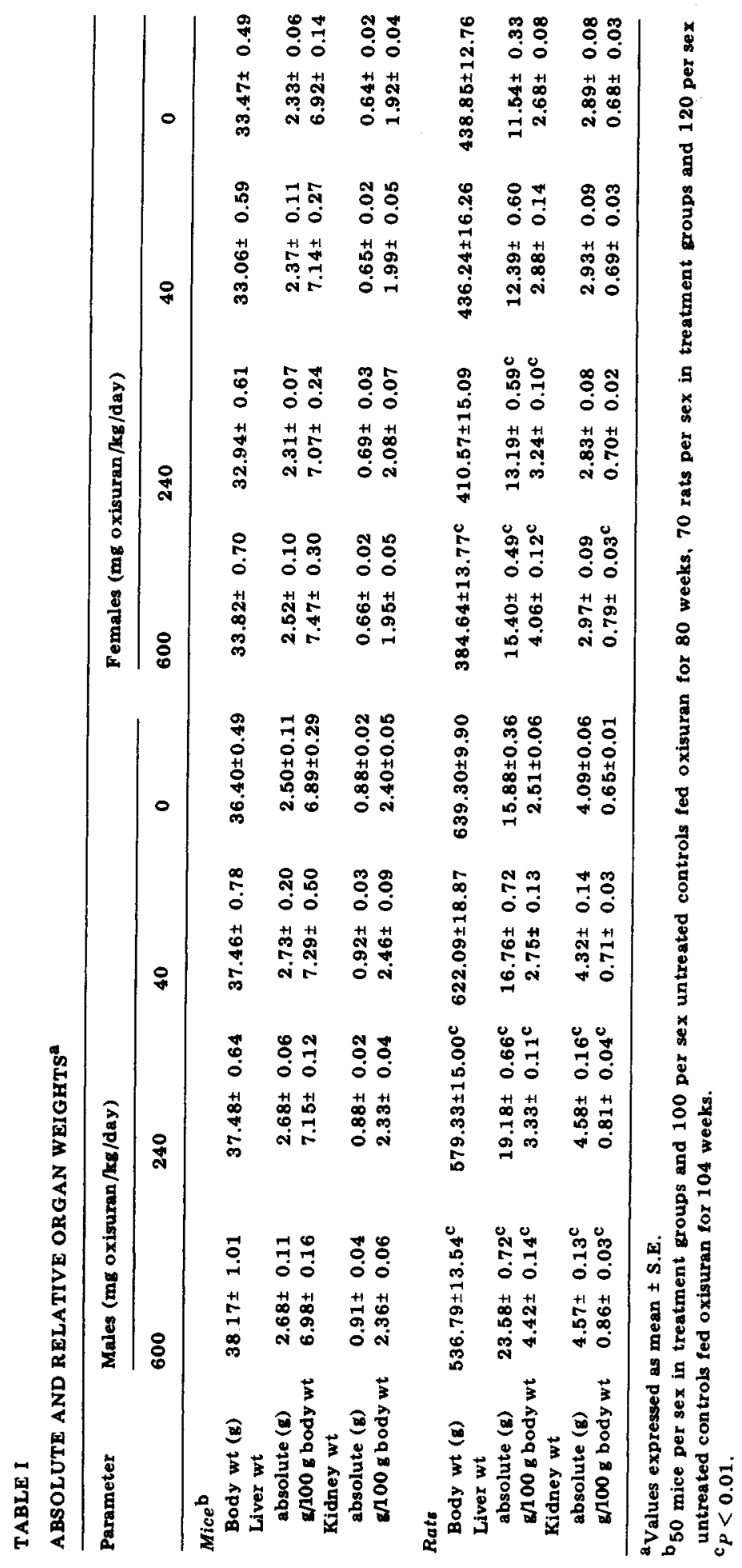


TABLE II

DISTRIBUTION OF TUMOR TYPES IN MICE GIVEN OXISURAN ORALLY FOR 80 WEEKS AND IN RATS FOR 104 WEEKS

\begin{tabular}{|c|c|c|c|c|c|c|c|c|}
\hline \multirow[t]{4}{*}{ Organ/tumor type $e^{b, c}$} & \multicolumn{8}{|c|}{ Treatment groups ${ }^{a}$} \\
\hline & \multicolumn{4}{|l|}{ Males } & \multicolumn{4}{|c|}{ Females } \\
\hline & \multicolumn{4}{|c|}{ Oxisuran } & \multicolumn{4}{|c|}{ Oxisuran } \\
\hline & $(600)$ & $(240)$ & $(40)$ & $(0)$ & $(600)$ & $(240)$ & $(40)$ & $(0)$ \\
\hline \multicolumn{9}{|l|}{ Mice } \\
\hline $\begin{array}{l}\text { Osteoma } \\
\text { Liver: }\end{array}$ & $\mathbf{0}$ & 1 & 2 & 2 & 3 & 4 & 6 & 6 \\
\hline Adenoma & 8 & 2 & 5 & 9 & 2 & 0 & 1 & 0 \\
\hline $\begin{array}{l}\text { Lung: } \\
\text { Alveologenic }\end{array}$ & & & & & & & & \\
\hline $\begin{array}{l}\text { adenocarcinoma } \\
\text { Mammary gland: }\end{array}$ & 17 & $7 * *$ & $5 * *$ & 22 & $12^{*}$ & 7 & 9 & 18 \\
\hline $\begin{array}{l}\text { Adenocarcinoma } \\
\text { Uterus: }\end{array}$ & 0 & 0 & 0 & 1 & 4 & 6 & 5 & 11 \\
\hline $\begin{array}{l}\text { Polyp } \\
\text { General: }\end{array}$ & - & - & - & - & 2 & 1 & 2 & 4 \\
\hline Lymphoid tumor & 8 & 8 & 9 & 19 & 22 & 21 & 19 & 30 \\
\hline Animals with benign tumors d,e & 9 & $3^{f}$ & 11 & 11 & 8 & 8 & 8 & 15 \\
\hline $\begin{array}{l}\text { Animals with malignant } \\
\text { tumors }\end{array}$ & 22 & 13 & 14 & 42 & 33 & 31 & 32 & 54 \\
\hline Animals with tumors & 26 & 16 & 18 & 48 & 34 & 35 & 36 & 60 \\
\hline \multicolumn{9}{|l|}{ Rats } \\
\hline Brain: & & & & & & & & \\
\hline $\begin{array}{l}\text { Astrocytoma } \\
\text { Liver: }\end{array}$ & 1 & 0 & 0 & 4 & 0 & 0 & 0 & 1 \\
\hline $\begin{array}{l}\text { Adenoma } \\
\text { Lymph node: }\end{array}$ & $8 * *$ & 1 & 0 & 2 & 7 & 3 & 2 & 4 \\
\hline Hemangioma & 0 & 0 & $\mathbf{0}$ & 4 & $\mathbf{0}$ & 0 & $\mathbf{0}$ & 1 \\
\hline Adenocarcinoma & 0 & 0 & 0 & 0 & 4 & 4 & 3 & 6 \\
\hline Fibroadenoma & 0 & 0 & 0 & 0 & $3^{* *}$ & $12 * *$ & 14 & 29 \\
\hline Pituitary: & & & & & & & & \\
\hline $\begin{array}{l}\text { Adenoma } \\
\text { Thyroid: }\end{array}$ & 9 & 6 & $3^{*}$ & 21 & $8 * *$ & 23 & 20 & 44 \\
\hline $\begin{array}{l}\text { Parafollicular cell } \\
\text { Tumor }\end{array}$ & 1 & 0 & 1 & 8 & $2 * *$ & $\mathbf{0}$ & $\mathbf{0}$ & 11 \\
\hline Uterus: & & & & & & & & \\
\hline $\begin{array}{l}\text { Polyp } \\
\text { General: }\end{array}$ & - & - & - & - & 10 & 7 & 5 & $\mathbf{9}$ \\
\hline Lymphoid tumor & 2 & 5 & 3 & 9 & 5 & 1 & 5 & 8 \\
\hline Animals with benign tumors ${ }^{d, e}$ & 17 & 10 & $7^{*}$ & 32 & $26 * *$ & 39 & 35 & 73 \\
\hline Animals with malignant tumors & 9 & 8 & 11 & 20 & 14 & 8 & 13 & 17 \\
\hline Animals with tumors & 25 & $16 *$ & $17^{*}$ & 48 & $33^{*}$ & 44 & 40 & 80 \\
\hline
\end{tabular}


a Numbers in parentheses indicate level of drug in $\mathrm{mg} / \mathrm{kg} / \mathrm{day}$; number of animals/sex/group indicated in Table I.

b Only those tumors where a frequency of 4 or more per group are listed, although all tumors are included in the overall incidence values.

cProbability analysis by life-table technique; $* P<0.05$ and $* * P<0.01$.

dSome animals may have had more than 1 tumor.

${ }^{\text {C }}$ Chi square test used overall tumor incidence with a frequency $>0.20$; values in the table with a superscript ${ }^{f}$ indicate result of exact probability test when incidence $<0.20$.

\section{TABLE III}

EARLIEST ONSET AND AVERAGE LATENCY PERIOD OF COMMON TUMORS IN MICE FED OXISURAN ORALLY FOR 80 WEEKS AND IN RATS FOR 104 WEEKS $^{\mathrm{a}}$

\begin{tabular}{|c|c|c|c|c|c|c|c|c|}
\hline \multirow[t]{4}{*}{ Tumor type } & \multicolumn{8}{|c|}{ Treatment groups } \\
\hline & \multicolumn{4}{|l|}{ Males } & \multicolumn{4}{|l|}{ Females } \\
\hline & \multicolumn{4}{|c|}{ Oxisuran } & \multicolumn{4}{|c|}{ Oxisuran } \\
\hline & $(600)$ & $(240)$ & $(40)$ & (0) & $(600)$ & $(240)$ & $(40)$ & $(0)$ \\
\hline \multicolumn{9}{|l|}{ Mice } \\
\hline $\begin{array}{l}\text { Lung } \\
\text { (Alveolar) }\end{array}$ & $\begin{array}{c}66 \\
{[76]}\end{array}$ & $\begin{array}{c}69 \\
{[78]}\end{array}$ & $\begin{array}{c}77 \\
{[79]}\end{array}$ & $\begin{array}{c}70 \\
{[79]}\end{array}$ & $\begin{array}{c}69 \\
{[78]}\end{array}$ & $\begin{array}{c}80 \\
{[80]}\end{array}$ & $\begin{array}{c}76 \\
{[80]}\end{array}$ & $\begin{array}{c}73 \\
{[79]}\end{array}$ \\
\hline Lymphoid & $\begin{array}{c}55 \\
{[75]}\end{array}$ & $\begin{array}{c}50 \\
{[74]}\end{array}$ & $\begin{array}{c}40 \\
{[70]}\end{array}$ & $\begin{array}{c}40 \\
{[68]}\end{array}$ & $\begin{array}{c}45 \\
{[71]}\end{array}$ & $\begin{array}{c}31 \\
{[70]}\end{array}$ & $\begin{array}{c}44 \\
{[71]}\end{array}$ & $\begin{array}{c}38 \\
{[72]}\end{array}$ \\
\hline $\begin{array}{l}\text { Liver cell } \\
\text { Adenoma }\end{array}$ & $\begin{array}{c}77 \\
{[80]}\end{array}$ & $\begin{array}{c}80 \\
{[80]}\end{array}$ & $\begin{array}{c}80 \\
{[80]}\end{array}$ & $\begin{array}{c}47 \\
{[75]}\end{array}$ & $\begin{array}{c}72 \\
{[76]}\end{array}$ & - & $\begin{array}{c}80 \\
{[80]}\end{array}$ & - \\
\hline $\begin{array}{l}\text { Mammary } \\
\text { Malignant }\end{array}$ & - & - & - & $\begin{array}{c}49 \\
{[49]}\end{array}$ & $\begin{array}{c}72 \\
{[76]}\end{array}$ & $\begin{array}{c}32 \\
{[72]}\end{array}$ & $\begin{array}{c}48 \\
{[66]}\end{array}$ & $\begin{array}{c}48 \\
{[63]}\end{array}$ \\
\hline Uterine polyp & - & - & - & - & $\begin{array}{c}80 \\
{[80]}\end{array}$ & $\begin{array}{c}80 \\
{[80]}\end{array}$ & $\begin{array}{c}80 \\
{[80]}\end{array}$ & $\begin{array}{c}58 \\
{[73]}\end{array}$ \\
\hline \multicolumn{9}{|l|}{ Rats } \\
\hline Lymphoid & $\begin{array}{c}72 \\
{[88]}\end{array}$ & $\begin{array}{c}52 \\
{[76]}\end{array}$ & $\begin{array}{c}45 \\
{[71]}\end{array}$ & $\begin{array}{c}78 \\
{[93]}\end{array}$ & $\begin{array}{c}36 \\
{[90]}\end{array}$ & $\begin{array}{c}80 \\
{[80]}\end{array}$ & $\begin{array}{c}78 \\
{[93]}\end{array}$ & $\begin{array}{c}73 \\
{[97]}\end{array}$ \\
\hline $\begin{array}{l}\text { Liver cell } \\
\text { Adenoma }\end{array}$ & $\begin{array}{c}71 \\
{[97]}\end{array}$ & $\begin{array}{c}102 \\
{[102]}\end{array}$ & - & $\begin{array}{c}86 \\
{[95]}\end{array}$ & $\begin{array}{c}104 \\
{[104]}\end{array}$ & $\begin{array}{c}78 \\
{[95]}\end{array}$ & $\begin{array}{c}72 \\
{[88]}\end{array}$ & $\begin{array}{c}104 \\
{[104]}\end{array}$ \\
\hline Mammary & - & - & - & - & 56 & 60 & 96 & 26 \\
\hline Malignant & - & - & - & - & [87] & {$[70]$} & [101] & [63] \\
\hline Benign & - & - & - & - & 68 & $\begin{array}{c}40 \\
{[82]}\end{array}$ & $\begin{array}{c}52 \\
{[87]}\end{array}$ & 48 \\
\hline $\begin{array}{l}\text { Pituitary } \\
\text { Adenoma }\end{array}$ & $\begin{array}{c}80 \\
{[101]}\end{array}$ & $\begin{array}{c}93 \\
{[102]}\end{array}$ & $\begin{array}{c}104 \\
{[104]}\end{array}$ & $\begin{array}{c}76 \\
{[100]}\end{array}$ & $\begin{array}{c}71 \\
{[93]}\end{array}$ & $\begin{array}{c}78 \\
{[92]}\end{array}$ & $\begin{array}{c}72 \\
{[94]}\end{array}$ & $\begin{array}{c}63 \\
{[94]}\end{array}$ \\
\hline Uterine polyp & - & - & - & -- & $\begin{array}{c}69 \\
{[93]}\end{array}$ & $\begin{array}{c}78 \\
{[100]}\end{array}$ & $\begin{array}{c}78 \\
{[88]}\end{array}$ & $\begin{array}{c}78 \\
{[101]}\end{array}$ \\
\hline
\end{tabular}

${ }^{a}$ Numbers in parentheses indicate level of drug in $\mathrm{mg} / \mathrm{kg} / \mathrm{day}$; number of animals per sex/group indicated in Table I; onset expressed as week when first tumor detected; average latency (in brackets) expressed as arithmetic mean of onset weeks/tumor-bearing animals. 
membranes as confirmed by electron microscopy not reported here. Centrilobular hepatocytic hypertrophy was noted in male mice and may have been related to compound administration although no attempts for further characterization were applied. The frequencies of other non-neoplastic lesions were comparable and attributed to aging.

In mice, the most common tumor types found were osteomas, alveologenic adenocarcinomas, and murine leukemia in both sexes, liver cell adenomas in males and mammary adenocarcinomas and uterine polyps in females (Table II). The incidence of lung carcinomas was significantly lower $(P<0.01)$ in mid and low dose males and significantly increased $(P<0.05)$ in high dose females. Although not confirmed statistically, lung carcinomas and liver cell adenomas (including hyperplastic nodules) in high dose males and lymphoid tumors in all female treated groups were increased in number in comparison with controls. No significant differences in onset and mean times of appearance were related to compound administration (Table III).

The most common tumor types found in rats were benign liver cell tumors, chromophobe adenomas, and leukemia in both sexes and mammary adenocarcinomas, mammary fibroadenomas, and uterine polyps in females (Table II). There was a significantly lower incidence of mammary fibroadenoma, pituitary chromophobe adenoma, and thyroid parafollicular cell tumors in high dose females $(P<0.01)$, contributing to an overall decrease in both benign tumors and the combination of benign and malignant classifications. Pituitary adenomas also were significantly reduced in low dose males $(P<0.05)$. The incidence of liver cell adenomas was increased in high dose animals of both sexes, showing a statistically significant increase in males only $(P<0.01)$. Mean time of appearance and onset were unaffected by compound administration (Table III).

\section{DISCUSSION}

It is generally accepted that extended periods of immunosuppression increase the risk of either viral or chemical carcinogenesis [9-12], and favor the growth and metastatic potential of transplanted tumors [13]. The development of spontaneous neoplasms in humans in an immunosuppressed state also is enhanced [14].

The effects of long-term immunosuppression on the incidence of spontaneously occurring tumors is much less definite and has not been studied in detail. Martinez demonstrated that thymectomy at birth resulted in a decreased incidence of mammary carcinomas in mice [15]. Susceptibility to these ordinarily occurring tumors in mice may have been restored by the immunologic reconstitution of the animal with implants of thymic tissue [16]. Freund's adjuvant which enhances immunosuppressive activity, administered subsequent to 3-methylcholanthrene, and croton oil-immunosuppression both enhanced the formation of malignant lymphomas [17-19]. Preliminary investigations with $\operatorname{Imuran}^{\circledR}$ (azathioprine) suggested that mammary tumorigenesis stimulated by pituitary grafting was accelerated by 
the immunosuppressive agent [20]. In long-term (14--16 months) investigations in female NZBXNZW mice with both azathioprine and ifosfamide (cyclophosphamide derivative), resulted in dose related increases in tumor frequency, predominantly lymphomas [21,22]. The sodium salt of azathioprine was administered as daily intraperitoneal injections, resulting in significant immunodepression after 348 days of therapy [12]. No evidence of increased incidence of spontaneous malignancies was apparent after 2 years.

Oxisuran has been shown to suppress tissue-mediated immune response by means of allograft rejection in rodents without causing suppression of humoral immune response [4,5]. Rodent carcinogenesis bioassays with oxisuran could provide further evidence of long-term effects on immunological surveillance mechanisms. Increased susceptibility to tumor development was not clearly demonstrated following 80 weeks and 104 weeks of compound administration in mice and rats, respectively. Of particular interest, mammary fibroadenomas, pituitary chromophobe adenomas, and thyroid parafollicular cell tumors in high dose rats had significantly reduced incidence rates.

Metabolism and pharmacokinetic investigations of oxisuran in 4 species (monkey, pig, dog, and rat) and in man, identified varying degrees of plasma levels of alcohol sulfoxides which contribute to the differential immunosuppressive activity of the parent compound [23]. The observed species differences in immunosuppressive activity, as well as in biotransformation, may account for the increased tendency towards lung carcinoma induction in female mice, and decreased incidence of mammary fibroadenomas, pituitary chromophobe adenomas, and thyroid parafollicular cell tumors in female rats. These effects may also suggest sex differences, either by decreased susceptibility or via metabolic transformation pathways. Also, compounds that prolong the survival of allografts commonly inhibit cellular proliferation by either crosslinking DNA or by preventing nucleic acid synthesis [7]. Variations in tissue proliferation rates could differentially affect the induction of neoplasia, depending on the age and sex of species, and the type, dose, and frequency of administration of the immunosuppressive agent [19]. Tumor induction may also be influenced by factors other than immunosuppression, and it is possible that oxisuran may exert its tumorigenic potential by mechanisms other than changes in immunocompetence. Nevertheless, the selective reduction of discrete types of tumors, such as mammary gland tumors, may indicate that the immune background may play a determining role in evoking spontaneous tumor rates in these organs. The increased lung tumor rates in mice and liver cell adenomas in rats could indicate that these represent target organs for the toxicity of this compound.

\section{ACKNOWLEDGEMENT}

This paper is dedicated to Dr. Doris Jaffé, deceased, who participated in the pathologic examination of these studies. 


\section{REFERENCES}

1 H.C. Outzen, R.P. Custer, G.J. Eaton et al., Spontaneous and induced tumor incidence in germ-free "nude" mice. J. Reticuloendothel. Soc., 17 (1975) 1.

2 L. Thomas, Reactions to homologous tissue antigens in relation to hypersensitivity, in H.S. Lawrence (Ed.), Cellular and Humoral Aspects of the Hypersensitive States, New York, Hoeber-Harper, 1959, pp. 529.

3 F.M. Burnet, The concept of immunological surveillance. Prog. Exp. Tumor Res., 13 (1970) 1.

4 H.H. Freedman, A.E. Fox, J. Shavel, Jr. and G.C. Morrison, Oxisuran: a differential inhibitor of cell-mediated hypersensitivity. Proc. Soc. Exp. Biol. Med., 139 (1972) 909.

5 A.E. Fox, D.L. Gawlak, D.L. Ballantyne, Jr. and H.H. Freedman, Influence of oxisuran, a differential inhibitor of cell-mediated hypersensitivity, on allograph survival and humoral immunity. Transplantation, 15 (1973) 389.

6 E. Gleichmann and H. Gleichmann, Immunosuppression and neoplasia. II. Is deficient immunesurveillance the only mechanism by which immunosuppression promotes neoplasia: A speculative review. Klin. Wochenschr., 51 (1973) 260.

7 G. Briziarelli, D. Abrutyn, J.A. Tornaben and E. Schwartz, Safety evaluation studies on oxisuran, a differential inhibitor of cell-mediated hypersensitivity. Toxicol. Appl. Pharmacol., 36 (1976) 49.

8 F.A. de la Iglesia, N.J. Barsoum, A. Gough, L. Mitchell, R.A. Martin, C. DiFonzo and E.J. McGuire, Carcinogenesis Bioassay of Prazepam in Rats and Mice. Toxicol. Appl. Pharmacol., 57 (1981) 39.

9 A.C. Allison and R.M. Friedman, Effects of immunosuppressants on Shope rabbit fibroma. J. Natl. Cancer Inst., 36 (1966) 859.

10 A.C. Allison and R.B. Taylor, Observations on thymectomy and carcinogenesis. Cancer Res., 27 (1967) 703.

11 M. DeJong, M.C. Coppee, F. DeHalleux, C. Beckers and H. Maisin, Immunosuppression and Carcinogenesis: effect of azathioprine on induction of sarcomas by 3-methylcholanthrene. Neoplasma, 24 (1977) 139.

12 B. Pirofsky, P.J. Dawson and R.H. Reid, Lack of oncogenicity with immunosuppressive therapy. Cancer, 45 (1980) 2096.

13 W.H. Isbister, S.D. Deodhar and G. Crile, Effects of adult thymectomy and antilymphocyte globulin treatment on metastases in an allogeneic mouse tumor system. Transplantation, 12 (1971) 322.

14 G.A. Hyman, Increased incidence of neoplasia in association with chronic lymphocytic leukemia. Scand. J. Haematol., 6 (1969) 6.

15 C. Martinez, Effect of early thymectomy on development of mammary tumours in mice. Nature; 203 (1964) 1188.

16 E.J. Yunis, C. Martinez, J. Smith, O. Stutman and R.A. Good, Spontaneous mammary adenocarcinoma in mice: influence of thymectomy and reconstitution with thymus grafts or spleen cells. Cancer Res., 29 (1969) 174.

17 H.G. Bluestein and I. Green, Croton oil induced suppression of the immune response of guinea pigs. Nature, $228(1970) 871$.

$18 \mathrm{~J}$. Stjernswärd, Further immunological studies of chemical carcinogenesis. J. Natl. Cancer Inst., 38 (1967) 515.

19 B.A. Rubin, Alteration of the homograft response as a determinant of carcinogenicity. Prog. Exp. Tumor Res., 14 (1971) 138.

20 H. Nagasawa, Effect of immunosuppression on spontaneous mammary tumorigenesis in mice. Obstet. Gynecol., 5 (1977) 219.

21 P.S. Mitrow, M. Fischer, G. Mitrou, P. Röttger and G. Holtz, The oncogenic effect of immunosuppressive (cytotoxic) agents in (NZB $\times$ NZW) mice. I. Long-term treatment with azathioprine and ifosfamide. Arzneim-Forsch., 29 (1979) 483. 
22 P.S. Mitrou, M. Fischer, G. Mitrou and P. Röttger, The oncogenic effect of immunosuppressive (cytotoxic) agents in (NZB $\times$ NZW) mice. II. Emergence of tumors in young animals treated with azathioprine and ifosfamide, including a histologic assessment of the neoplasms. Arzneim-Forsch., 29 (1979) 663.

23 F.J. DiCarlo, Interspecies comparisons of oxisuran metabolism and pharmacokinetics. Drug Metab. Rev., 10 (1979) 225. 